DOI: $10.5455 / 2320-1770.1 j \operatorname{cog} 20140925$

Research Article

\title{
Dynamics of contraceptive use among schedule caste women in Uttar Pradesh
}

\author{
Mahesh Nath $\operatorname{Singh}^{1}{ }^{*}$, Niyati Joshi ${ }^{2}$ \\ ${ }^{1}$ Senior Research Officer, Public Health Foundation of India at National Institute of Medical Statistics (ICMR), Ansari \\ Nagar, New Delhi, India \\ ${ }^{2}$ Deputy Director, Ministry of Commerce and Industry, Government of India, New Delhi, India
}

Received: 14 June 2014

Accepted: 1 July 2014

\section{*Correspondence:}

Dr. Mahesh Nath Singh,

E-mail: maheshnsingh@gmail.com

(C) 2014 Singh MN et al. This is an open-access article distributed under the terms of the Creative Commons Attribution Non-Commercial License, which permits unrestricted non-commercial use, distribution, and reproduction in any medium, provided the original work is properly cited.

\begin{abstract}
Background: Scheduled caste is socially and economically disadvantaged population and contributes to one fifth of India's population. Population policy (2002), government of India, has set the task of addressing unmet need for contraception in order to achieve the medium term objective of bringing the total fertility rate down to replacement level by the year 2010 .

Methods: The data used for the paper has been taken from Reproductive and Child Health (RCH) Survey round-II (2001-02) phase-I of Uttar Pradesh. Information of only scheduled caste women has been used for analysis. Bi-variate and logistic regression analysis was carried out.

Results: There is positive relationship between knowledge of traditional methods, level of education and standard of living; which is expected to have inverse relationship. Use of contraceptive methods among these groups of women is substantially low, but it follows an expected trend. Government health care institutions remain the main source of contraception for scheduled caste women in the study area.

Conclusions: Results from the logistic analysis give a clear picture that women with the information/knowledge are more likely to use the method in the near future.
\end{abstract}

Keywords: Contraception, Informed choice, Scheduled caste women

\section{INTRODUCTION}

India is the second largest populous country in the world, where information about the knowledge of family planning methods and use of contraceptive methods is an important issue for solving the increasing population. In India, Uttar Pradesh is one of the most populated states and is home to almost sixteen percent population of India. The contribution of scheduled caste population is about one fifth of the total population. In the state, the share of the ST population did not change much between 19811991 but that of the scheduled caste increased by about one percent point. The SC experienced higher growth rate during 1981-1991, 2.70 percent annually compared to 2.13 percent for the entire population. However, this is at least partly due to a change in classification. ${ }^{1}$ Scheduled Caste are those caste identified by the Government of India as socially and economically disadvantaged and in need of protection from social injustice and exploitation. ${ }^{2}$ More importantly, most of them are illiterate and are far away from receptiveness of new technological development.

Knowledge of the contraception method is nearly universal in Uttar Pradesh; with 98 percent of currently married women recognize at least one method of contraception and at least one modern method of contraception. Female sterilization (97 percent) is the most widely known method of contraception in Uttar Pradesh, followed by male sterilization (93 percent). 
There is a little difference ( 7 percent point) by residence in knowledge of female sterilization and the knowledge of the officially sponsored spacing methods (Pills, IUD, and condom) is less widespread. The known spacing methods are the pills (85 percent), condom (83 percent) and IUD (74 percent). There is large difference in knowledge of spacing method by residence, for example only 69 percent of rural women known about the IUD, compared with 93 percent of urban women. Although knowledge of spacing method remained lower than knowledge of sterilization, knowledge of spacing method has increased substantially since 1992-93. During 199899 (NFHS-2), in Uttar Pradesh overall about 28 percent of currently married women were using one or the other type of family planning methods. ${ }^{3}$ Proportion of female sterilization to total contraceptive prevalence rate was about 53 percent, modern spacing method was 23 percent and traditional method was 20 percent. NFHS-2 recorded current use of contraception among Scheduled Caste women as 24.8 percent; out of which 58.5 percent is female sterilization, 23 percent is traditional method and 14 percent is modern spacing method. ${ }^{4}$ This result although puts scheduled caste women in slightly better position than overall all women of the state in terms of contraceptive use, however, the specific study on scheduled caste women is essential as these group of women is less studied. On the contrary, total fertility rate of scheduled caste was higher (4.44) than state as a whole (3.99). Hence there is need to study the dynamics of contraceptive use among scheduled caste women, as about one fifth of total population of the state belongs to this group of population, any change in fertility rate can have sufficient effect on the population growth of the state.

\section{Review of literature}

Contraceptive competence or the ability to use particular method efficiency is associated with higher education, and higher level of education, and high level of contraceptive knowledge and interspousal communication. In Indian context, there are two main reasons for the need to acquire a deeper understanding of the determinants of contraceptive method choices. First, there is a growing realization that the number of women in their reproductive ages is likely to grow for some time to come, a feature unfavorable to fertility decline unless these couple space their next birth; a realization that has promoted spacing methods as opposed to the earlier stress on sterilization. Second, Indian studies have by and large, concentrated on the reason for non-acceptance which, at best, suggest the determinants of choice indirectly. ${ }^{5}$ This study tells us that the response from district official of the administration as well as health and family welfare departments, lead us to conclude that there is an urgent need to eliminate existing information gaps by meeting the information needs of both administration and health officials of the family planning programme. ${ }^{6}$ Son preference as a determining factor in contraceptive acceptance and birth control is fast changing, especially in regions where fertility is on the decline. One findings suggest that family size preferences is apparently more important than gender preferences in determining contraceptive use-both, terminal and spacing methods. The lack of sex preferences also confirms an absence of son preferences, on contraceptive use. In general, the tendency of acceptor had couples was to use contraception not to space births in term of preferred sex of the children, but limit to family size. ${ }^{7}$ A study based on NFHS-2 revealed that the prevalence of contraception was similar in SC/ST women and other caste except that it was slightly lower, among the literate SC/ST in comparison to the literate women of other caste group. Regarding the desire to have more children for women with a given number of living children, it was slightly higher among these SC/ST women in comparison to other caste group. ${ }^{8}$ The small family norm becomes acceptable when the general health conditions are good, child mortality is low and there is social and economic development. Only 56 percent of the Muslim women are agreeing to this norm. ${ }^{9}$

Weak links between individual autonomy and fertility indicators when analyzing national family health survey data in India. ${ }^{10}$ On the other hand they suggest that literacy among women in a community can generally influences an individual women's reproductive behaviour beyond that of her own education. Although educated women are more likely to need and use family planning, this is not directly linked to autonomy since, for 43.6 percent of the women in the current study, it is the husband who decides they should use family planning (from 38.5 percent of non-literate women to 50.4 percent of university-educated women. ${ }^{11}$ Hence, studying the contraceptive use among scheduled caste women would be very important to understand the dynamics of use. The main focus of the present paper is to understand the dynamics of contraceptive use among scheduled caste women in Uttar Pradesh specifically to understand the level of knowledge and current use of contraceptive methods by understanding the informed choice of contraception in relation to future intention to use among non-users.

\section{METHODS}

The basic data used for the present term paper has been taken from reproductive and child health survey round-II (2001-02) phase-I of Uttar Pradesh. In the present study, information of only the scheduled caste women has used. Present study applies percentages and cross tabulation.

\section{RESULTS}

\section{Knowledge of contraceptive method}

Knowledge of contraceptive methods is pre requisite for the use of contraception and very important in making decision about its use. Result shows that among scheduled caste women knowledge of any modern 
method of contraception is universal (98 percent) in Uttar Pradesh across all sections of the caste. The level of knowledge of any methods of contraception may not be very good indicator for the study of dynamics of contraceptive use. Thus here an attempt is also made to assess the knowledge of all the modern methods of contraception. Table 1 show that only about 44 percent of scheduled caste women have knowledge of all the modern methods of contraception.

Among scheduled caste women in Uttar Pradesh, knowledge of female sterilization is universal among all section of caste, however knowledge of laparoscopy quite lower than that of tubectomy. Result exhibits that among
SC women in Uttar Pradesh knowledge about 70 percent have knowledge of male sterilization, 34 percent have knowledge of vasectomy and only 22 percent have knowledge of non-scalpel vasectomy.

Knowledge of specific modern spacing methods (Table 1) shows that pills (82.4 percent) is more popular than condom (71.9 percent) IUD (62.4 percent) and injection (41.5 percent) among scheduled caste women in Uttar Pradesh. Closer look at the result (Table 1) shows that there is strong positive relationship between socioeconomic condition and knowledge of any specific method of contraception, except for traditional method and herbs.

Table 1: Knowledge of contraceptive method of currently married women.

\begin{tabular}{|c|c|c|c|c|c|c|c|c|c|}
\hline \multirow[b]{2}{*}{ Contraceptive method } & \multirow[b]{2}{*}{ Total } & \multicolumn{2}{|c|}{ Residence } & \multicolumn{3}{|c|}{ Education } & \multicolumn{3}{|c|}{ Standard of living index } \\
\hline & & Rural & Urban & $\begin{array}{l}\text { Non } \\
\text { literate }\end{array}$ & $\begin{array}{l}0-9 @ \\
\text { year }\end{array}$ & $\begin{array}{l}10 \text { years } \\
\& \text { above }\end{array}$ & Low & Medium & High \\
\hline Any modern method & 98.4 & 98.2 & 99.3 & 98.1 & 99.6 & 99.0 & 98.1 & 98.9 & 99.8 \\
\hline Any modern spacing method & 88.3 & 86.7 & 95.1 & 86.5 & 95.4 & 97.4 & 86.6 & 91.5 & 98.4 \\
\hline All modern method & 44.4 & 39.7 & 64.4 & 40.1 & 57.8 & 78.2 & 38.8 & 54.2 & 77.0 \\
\hline Female sterilization & 97.0 & 96.6 & 99.0 & 96.5 & 99.1 & 98.7 & 96.6 & 97.8 & 99.4 \\
\hline Tubectomy & 78.0 & 76.5 & 84.3 & 77.0 & 80.8 & 88.1 & 77.0 & 77.9 & 84.2 \\
\hline Laparoscopy & 44.8 & 42.6 & 54.0 & 42.3 & 53.1 & 62.8 & 44.2 & 44.8 & 51.4 \\
\hline Male sterilization & 70.1 & 67.6 & 80.7 & 67.9 & 77.1 & 87.8 & 67.3 & 74.7 & 88.1 \\
\hline Vasectomy & 33.8 & 31.7 & 43.0 & 31.5 & 40.6 & 53.2 & 32.5 & 34.2 & 47.3 \\
\hline No scalpel vasectomy & 22.2 & 19.8 & 32.6 & 19.3 & 29.9 & 49.7 & 19.6 & 25.6 & 40.3 \\
\hline IUD/Loop & 62.4 & 58.1 & 80.4 & 58.6 & 74.4 & 90.7 & 57.4 & 72.2 & 88.3 \\
\hline Pills & 82.4 & 80.0 & 92.4 & 80.0 & 91.4 & 95.8 & 79.4 & 88.8 & 96.3 \\
\hline Daily & 54.2 & 51.5 & 65.6 & 50.4 & 67.0 & 78.8 & 51.6 & 59.0 & 67.9 \\
\hline Weekly & 26.9 & 23.8 & 40.1 & 23.3 & 37.8 & 56.4 & 23.3 & 33.6 & 46.3 \\
\hline Condom/nirodh & 71.9 & 68.9 & 84.6 & 69.0 & 82.5 & 89.1 & 68.7 & 77.6 & 90.3 \\
\hline Sponge (today) & 5.3 & 4.8 & 7.4 & 4.4 & 7.4 & 14.4 & 4.4 & 6.2 & 11.5 \\
\hline Injection & 41.5 & 40.7 & 45.1 & 39.3 & 47.7 & 61.2 & 40.6 & 43.2 & 47.3 \\
\hline Norplant & 2.2 & 2.1 & 2.9 & 1.8 & 3.1 & 6.7 & 2.0 & 2.4 & 4.1 \\
\hline Contraceptive herbs & 15.8 & 16.6 & 14.9 & 15.0 & 18.4 & 21.2 & 15.8 & 15.8 & 16.5 \\
\hline Any traditional method & 42.3 & 42.5 & 41.6 & 41.1 & 46.4 & 50.0 & 42.3 & 41.8 & 44.0 \\
\hline
\end{tabular}

\section{Contraceptive use}

The use of contraceptive methods is very essential in view of bringing down fertility rate, and our knowledge on distribution of women by background characteristics who are using contraceptive method is very essential from policy and planning point of view. Result of contraceptive prevalence rate (Table 2) shows that only 30 percent of scheduled caste women/men in Uttar Pradesh are currently using one or the other methods of contraception. Among rural couple, use of contraceptive is much lesser (27.4 percent) than that of urban couple (42.6 percent); and use of contraception increases with increase in level of education of women and standard of living index.
Among modern spacing methods of contraception, condom (14.8 percent) remains most popular methods of contraception across all section of women and it is followed by and oral pills (6.4 percent) but at lower level. Currently about 16 percent of women are using periodic abstinence/Rhythm method of contraception and about 7 percent are using withdrawal. The use of traditional methods of contraception is slightly higher among rural women, illiterate women and women from low standard of living index. To understand the dynamics of contraceptive use, understanding demographic characteristics of the women is very essential, in this regards, age of women, number of surviving sons and daughters are considered. Result (Table 3) shows a constant rise in use any methods of contraception by age 
group and quite similar trend is also observed in the use of traditional methods of contraception, but different trend is observed in the use of modern methods of contraception.

Table 2: Contraceptive prevalence rate.

\begin{tabular}{|c|c|c|c|c|c|c|c|c|c|}
\hline \multirow[b]{2}{*}{ Method } & \multirow[b]{2}{*}{ Total } & \multicolumn{2}{|c|}{ Residence } & \multicolumn{3}{|c|}{ Education } & \multicolumn{3}{|c|}{ Standard of living index } \\
\hline & & Rural & Urban & $\begin{array}{l}\text { Non } \\
\text { literate }\end{array}$ & $\begin{array}{l}0-9 @ \\
\text { year }\end{array}$ & $\begin{array}{l}10 \text { years } \\
\& \text { above }\end{array}$ & Low & Medium & High \\
\hline $\begin{array}{l}\text { Percent distribution of } \\
\text { women/husbands using }\end{array}$ & 26.1 & 23.4 & 37.3 & 25.1 & 27.8 & 38.5 & 21.9 & 34.5 & 47.7 \\
\hline \multicolumn{10}{|l|}{ Respondent /husbands using } \\
\hline Any modern method & 19.4 & 17.1 & 29.2 & 18.4 & 21.3 & 31.1 & 15.4 & 28.0 & 38.9 \\
\hline Any traditional method & 6.7 & 6.4 & 7.9 & 6.6 & 6.6 & 7.4 & 6.5 & 6.6 & 8.6 \\
\hline \multicolumn{10}{|l|}{ Modern method } \\
\hline Not using any FP method & 73.9 & 76.6 & 62.8 & 74.9 & 72.2 & 61.5 & 78.1 & 65.5 & 52.5 \\
\hline Female sterilization & 12.8 & 11.8 & 17.2 & 13.3 & 11.5 & 8.3 & 11.2 & 10.4 & 20.4 \\
\hline Vasectomy & 0.1 & 0.1 & 0.4 & 0.1 & 0.2 & - & 0.1 & 0.2 & 0.6 \\
\hline NSV & 0.1 & 0.1 & 0.1 & 0.1 & - & - & 0.1 & 0.1 & - \\
\hline IUD/loop & 0.7 & 0.5 & 1.4 & 0.4 & 1.2 & 4.2 & 0.4 & 0.8 & 3.1 \\
\hline Pills & 1.7 & 1.5 & 2.4 & 1.4 & 2.0 & 5.1 & 1.1 & 3.0 & 3.9 \\
\hline Condom/nirodh & 3.9 & 3.0 & 7.5 & 2.9 & 6.2 & 12.8 & 2.4 & 7.2 & 10.7 \\
\hline \multicolumn{10}{|l|}{ Traditional method } \\
\hline Rhythms/periodic abstinence & 4.4 & 4.1 & 5.4 & 4.4 & 4.1 & 4.5 & 4.3 & 4.0 & 5.8 \\
\hline Withdrawal & 1.9 & 0.8 & 2.2 & 1.7 & 2.2 & 2.9 & 1.7 & 2.3 & 2.5 \\
\hline Any other modern method & 0.2 & 0.2 & 0.2 & 0.1 & 0.2 & 0.6 & 0.2 & 0.2 & 0.2 \\
\hline
\end{tabular}

Table 3: Use of contraception by some demographic characteristics.

\begin{tabular}{|c|c|c|c|c|c|c|}
\hline \multirow{2}{*}{$\begin{array}{l}\text { Demographic } \\
\text { characteristic }\end{array}$} & \multicolumn{4}{|c|}{ Percentage of women / their husband using total } & \multicolumn{2}{|c|}{$\begin{array}{l}\text { Percent distribution of } \\
\text { women/their husbands by } \\
\text { use of contraception }\end{array}$} \\
\hline & $\begin{array}{l}\text { Modern } \\
\text { method }\end{array}$ & $\begin{array}{l}\text { Traditional } \\
\text { method }\end{array}$ & $\begin{array}{l}\text { Any } \\
\text { method }\end{array}$ & $\begin{array}{l}\text { Not using } \\
\text { any method }\end{array}$ & Ever & Never \\
\hline \multicolumn{7}{|c|}{ Age group (In years) } \\
\hline $15-19$ & 2.4 & 3.7 & 7.5 & 92.4 & 2.4 & 97.6 \\
\hline $20-24$ & 8.0 & 5.2 & 17.0 & 83.0 & 6.0 & 94.0 \\
\hline $25-29$ & 21.0 & 6.0 & 32.2 & 67.8 & 7.1 & 92.9 \\
\hline $30-34$ & 30.1 & 7.8 & 41.8 & 58.2 & 9.5 & 90.5 \\
\hline $35-39$ & 30.6 & 9.3 & 42.6 & 57.4 & 7.4 & 92.6 \\
\hline $40-44$ & 32.5 & 9.8 & 43.6 & 56.4 & 3.9 & 96.1 \\
\hline \multicolumn{7}{|c|}{ Surviving children } \\
\hline 0 & 0.6 & 1.3 & 2.4 & 97.4 & 1.7 & 98.3 \\
\hline 1 & 5.5 & 5.4 & 13.5 & 86.5 & 3.7 & 96.3 \\
\hline 2 & 14.6 & 6.8 & 25.6 & 74.4 & 7.5 & 92.5 \\
\hline $3+$ & 29.4 & 8.4 & 41.8 & 52.8 & 8.0 & 91.6 \\
\hline \multicolumn{7}{|l|}{ Surviving sons } \\
\hline 0 & 3.0 & 3.5 & 8.3 & 91.6 & 3.2 & 96.8 \\
\hline 1 & 13.4 & 6.1 & 23.4 & 76.6 & 5.8 & 94.2 \\
\hline 2 & 33.7 & 8.7 & 46.7 & 53.3 & 8.6 & 91.4 \\
\hline $3+$ & 31.4 & 9.0 & 43.3 & 56.7 & 9.5 & 90.5 \\
\hline \multicolumn{7}{|c|}{ Surviving daughters } \\
\hline 0 & 9.5 & 3.9 & 16.7 & 83.2 & 3.6 & 96.4 \\
\hline 1 & 23.9 & 7.4 & 35.5 & 64.5 & 6.2 & 93.8 \\
\hline 2 & 24.5 & 7.0 & 36.0 & 64.0 & 8.7 & 91.3 \\
\hline $3+$ & 23.2 & 9.8 & 36.5 & 63.5 & 8.2 & 91.8 \\
\hline
\end{tabular}


Use of modern methods is lowest (2.4 percent) among the age group 15-19 as the desire to have children is universal and highest in lower age group and highest (32.5 percent) among the age group 40-44 as they might have achieved their desired number of children. Number of surviving children not only determines use of contraception but also methods of contraception. Results show a strong positive relationship between use of contraception and number of surviving children.

The use of contraception jumps from 2.4 percent for women with no surviving child to 13.5 percent among women having one child, it goes to 25.6 percent among women having 2 surviving children and about 42 percent among women with 3 or more surviving children. In patriarchal society, desire to have son is found to be very strong, thereby study of dynamics of contraceptive use in patriarchal society like India would remain incomplete without the consideration of number of surviving son. This indirectly indicates the son preference among scheduled caste women in Uttar Pradesh.

\section{Source of modern contraceptive method}

Government/municipal hospital and community health center are good source of family planning methods (Male/female sterilization, IUD, pill and condom). While government doctor and nurses are little beneficiaries for these contraceptive methods, chemists are also good source for modern contraceptive methods.

Table 4: Source of modern contraceptive method.

\begin{tabular}{|c|c|c|c|c|c|}
\hline Source & $\begin{array}{l}\text { Female } \\
\text { steriliz } \\
\text { ation }\end{array}$ & $\begin{array}{l}\text { Male } \\
\text { steriliz } \\
\text { ation }\end{array}$ & $\begin{array}{l}\text { IUD/ } \\
\text { loop }\end{array}$ & Pill & $\begin{array}{l}\text { Condom } \\
\text { /nirodh }\end{array}$ \\
\hline \multicolumn{6}{|c|}{ Percent distribution of current users by source of supply } \\
\hline $\begin{array}{l}\text { Govt./ } \\
\text { municipal } \\
\text { hospital }\end{array}$ & 36.9 & 34.7 & 36.9 & 36.2 & 35.0 \\
\hline $\mathrm{CHC} / \mathrm{PHC}$ & 24.4 & 26.5 & 23.2 & 23.4 & 25.0 \\
\hline $\begin{array}{l}\text { Family } \\
\text { planning } \\
\text { camp/RCH } \\
\text { camp }\end{array}$ & 5.6 & 5.2 & 5.6 & 5.4 & 4.5 \\
\hline Sub-center & 1.8 & 1.7 & 1.9 & 1.8 & 1.8 \\
\hline $\begin{array}{l}\text { Private } \\
\text { hospital }\end{array}$ & 4.1 & 4.4 & 3.9 & 4.1 & 3.8 \\
\hline $\begin{array}{l}\text { Govt. } \\
\text { doctor }\end{array}$ & 0.2 & 0.2 & 0.1 & 0.2 & 0.1 \\
\hline $\begin{array}{l}\text { Private } \\
\text { doctor }\end{array}$ & 1.2 & 0.9 & 0.4 & 1.1 & 1.2 \\
\hline $\begin{array}{l}\text { Govt. nurse } \\
\text { /ANM }\end{array}$ & 1.7 & 1.8 & 1.6 & 0.3 & 1.9 \\
\hline $\begin{array}{l}\text { Private } \\
\text { nurse }\end{array}$ & 0.3 & 0.3 & 0.4 & 0.3 & 0.4 \\
\hline Chemist & 0.0 & 0.0 & 19.6 & 20.4 & 21.1 \\
\hline Others & 1.7 & 1.7 & 2.0 & 1.8 & 1.7 \\
\hline
\end{tabular}

The method specific advice would also give better picture of the strength of the workers of the government run health care institutions. Result (Table 5) shows that most of the women (57 percent) were informed of female sterilization, followed by pills (20.2 percent).

Because if the woman is afraid of sterilization and her health do not allow using pills, or if the couple wants to space between birth and pill does not suit the women, what methods of contraception should she use?

This will definitely bring down the use of contraception and increase the unmet need for family planning. Intention to use (of contraception) is likely to lead to use of contraception, and use of contraception is very essential to curb down fertility.

The method preference of scheduled caste women who are currently not using any methods of contraception. Result (Table 5) shows that majority of women (52 percent) prefer to use female sterilization followed by pills (26 percent).

Predominant preference of female sterilization and pill can be due to the promotion these methods of contraception by the health workers. 
Table 5: Advice on contraceptive use and future intention to use.

\begin{tabular}{|c|c|c|c|c|c|c|c|c|c|}
\hline \multirow[b]{2}{*}{ Method } & \multirow[b]{2}{*}{ Total } & \multicolumn{2}{|c|}{ Residence } & \multicolumn{3}{|c|}{ Education } & \multicolumn{3}{|c|}{ Standard of living index } \\
\hline & & Rural & Urban & $\begin{array}{l}\text { Non } \\
\text { literate }\end{array}$ & $\begin{array}{l}0-9 @ \\
\text { year }\end{array}$ & $\begin{array}{l}10 \text { years } \\
\& \text { above }\end{array}$ & Low & Medium & High \\
\hline $\begin{array}{l}\text { Current non-users advised } \\
\text { by ANM/ health worker to } \\
\text { use of contraceptive method }\end{array}$ & 7.0 & 7.1 & 6.4 & 6.5 & 8.9 & 9.7 & 6.9 & 7.5 & 6.2 \\
\hline \multicolumn{10}{|c|}{ Women who were advice by method } \\
\hline Female sterilization & 57.1 & 60.7 & 36.5 & 60.2 & 44.6 & 55.2 & 60.6 & 50.8 & 20.0 \\
\hline Male Sterilization & 5.8 & 5.1 & 9.6 & 5.7 & 6.2 & 5.6 & 4.5 & 7.9 & 20.0 \\
\hline IUD/Loop & 7.5 & 15.4 & 8.6 & 6.1 & 18.5 & 11.1 & 7.1 & 14.3 & 13.3 \\
\hline Pill & 20.2 & 19.0 & 26.9 & 19.7 & 21.5 & 22.2 & 20.4 & 15.9 & 33.3 \\
\hline Condom/Nirodh & 7.8 & 7.1 & 11.5 & 7.6 & 9.2 & 5.6 & 6.7 & 11.1 & 13.3 \\
\hline Other method & 0.3 & - & 0.3 & 0.4 & - & 0.4 & 0.4 & - & 0.3 \\
\hline $\begin{array}{l}\text { Current non-user intended to } \\
\text { use contraceptive in future }\end{array}$ & 26.9 & 26.5 & 29.2 & 25.2 & 32.9 & 41.6 & 25.8 & 30.2 & 33.3 \\
\hline \multicolumn{10}{|c|}{ Women who intend to use contraceptive in future by preferred method } \\
\hline Female Sterilization & 52.9 & 52.9 & 52.9 & 51.8 & 56.3 & 57.0 & 50.9 & 59.5 & 57.6 \\
\hline Male Sterilization & 1.2 & 1.1 & 1.6 & 1.0 & 1.6 & 2.5 & 1.4 & 0.8 & 1.2 \\
\hline IUD/loop & 2.5 & 1.8 & 5.3 & 1.6 & 4.9 & 6.3 & 2.1 & 2.7 & 5.9 \\
\hline Pill & 26.4 & 27.2 & 22.5 & 29.0 & 18.0 & 16.5 & 20.0 & 19.8 & 14.1 \\
\hline Condom/nirodh & 3.9 & 3.2 & 7.4 & 3.2 & 5.3 & 8.9 & 2.7 & 5.3 & 14.1 \\
\hline Other traditional method & 2.0 & 2.2 & 1.2 & 2.0 & 1.6 & 3.8 & 2.1 & 1.5 & 2.4 \\
\hline Other method & 10.7 & 11.1 & 9.0 & 10.8 & 12.2 & 5.1 & 11.4 & 9.9 & 10.7 \\
\hline
\end{tabular}

Table 6: Future fertility intention.

\begin{tabular}{|c|c|c|c|c|c|c|c|c|c|}
\hline \multirow[b]{2}{*}{ Method } & \multirow[b]{2}{*}{ Total } & \multicolumn{2}{|c|}{ Residence } & \multicolumn{3}{|c|}{ Education } & \multicolumn{3}{|c|}{ Standard of living index } \\
\hline & & Rural & Urban & $\begin{array}{l}\text { Non } \\
\text { literate }\end{array}$ & $\begin{array}{l}0-9 @ \\
\text { year }\end{array}$ & $\begin{array}{l}10 \text { years } \\
\text { \& above }\end{array}$ & Low & Medium & High \\
\hline $\begin{array}{l}\text { Women reported not desiring } \\
\text { additional children }\end{array}$ & 39.2 & 38.6 & 42.8 & 41.1 & 30.9 & 28.9 & 39.4 & 38.0 & 41.2 \\
\hline Desiring the next child to be & 55.0 & 55.7 & 51.7 & 53.0 & 64.5 & 61.7 & 54.9 & 55.9 & 53.3 \\
\hline Boy & 36.4 & 37.1 & 32.0 & 37.4 & 34.1 & 25.2 & 37.1 & 35.2 & 26.9 \\
\hline Girl & 6.2 & 6.1 & 6.8 & 5.9 & 6.3 & 9.3 & 5.9 & 6.4 & 10.2 \\
\hline $\begin{array}{l}\text { Desiring next child after two } \\
\text { years (less than } 24 \text { months) }\end{array}$ & 50.6 & 49.6 & 55.8 & 50.6 & 51.8 & 44.9 & 49.4 & 54.3 & 57.4 \\
\hline
\end{tabular}

\section{Future fertility intention}

There is negative relationship between not desiring to have additional children and level of education. Percentage of women desiring the next child to be boy (36 percent) is higher in comparison to girls (6.2 percent) and desire for next child to be boy is declining with level of education.

\section{Reason for discontinuation of use and non-use of contraceptive method}

Wanted child (39.8 percent) is one of the most important reasons for discontinuation of family planning method, which is more in urban areas for women with higher level of education and higher standard of living index. It is interesting to note that substantial percentage of women (15.0 percent) have reported method failure as main cause of discontinuation of contraceptive use and it has negative relationship with place of residence, level of education and standard of living. Lack of supply or difficulty to get method (3.5 percent) is also another important reason for discontinuation of family planning methods.

The reasons for non-use of contraception (Table 7) shows that among scheduled caste women in Uttar Pradesh, health related reason (23.8 percent) is the most important reason for non-use of any contraceptive method, followed by husband opposed ( 8.7 percent), afraid of sterilization (7.3 percent) and lack of knowledge of family planning (6.0 percent). However, deeper look at the result reveals 
that the lack of knowledge (if we combine lack of knowledge of family planning method, not like existing method, cannot work after sterilization and worry about side effect) as the most dominant reason for non-use of contraception.

Table 7: Reason for discontinuation of use and non-use of contraceptive methods.

\begin{tabular}{|c|c|c|c|c|c|c|c|c|c|}
\hline \multirow[b]{2}{*}{ Reason } & \multirow[b]{2}{*}{ Total } & \multicolumn{2}{|c|}{ Residence } & \multicolumn{3}{|c|}{ Education } & \multicolumn{3}{|c|}{ Standard of living index } \\
\hline & & Rural & Urban & $\begin{array}{l}\text { Non } \\
\text { literate }\end{array}$ & $\begin{array}{l}0-9 @ \\
\text { year }\end{array}$ & $\begin{array}{l}10 \text { years } \\
\& \text { above }\end{array}$ & Low & Medium & High \\
\hline \multicolumn{10}{|c|}{ Number of past users (Current non-user) reason for discontinuation } \\
\hline Wanted child & 39.8 & 37.9 & 45.1 & 34.4 & 48.7 & 57.7 & 14.1 & 28.8 & 59.0 \\
\hline Method failed/became pregnant & 15.0 & 16.8 & 9.8 & 16.0 & 13.2 & 11.5 & 16.8 & 15.1 & 5.1 \\
\hline Supply not available & 3.5 & 3.0 & 4.9 & 2.1 & 6.6 & - & 2.0 & 4.1 & 10.3 \\
\hline Difficult to get method & 1.3 & 1.7 & - & 1.4 & 1.3 & - & 1.5 & 1.4 & - \\
\hline Weakness/inability to work & 5.7 & 4.3 & 9.8 & 5.7 & 7.2 & 3.8 & 3.0 & 15.1 & 2.6 \\
\hline Body ache/backache & 0.6 & 0.9 & - & 0.9 & - & - & 0.5 & - & - \\
\hline Cramps & 0.3 & 0.4 & - & 0.5 & - & - & 0.5 & - & - \\
\hline Weight gain & 0.6 & 0.9 & - & 0.5 & 1.3 & - & - & 2.7 & - \\
\hline Irregular periods & 3.2 & 3.0 & 3.7 & 4.2 & 1.3 & - & 3.0 & 5.5 & - \\
\hline Excessive bleeding & 3.2 & 3.9 & 1.2 & 4.7 & - & - & 4.0 & 2.7 & - \\
\hline Lack of pleasure & 2.2 & 2.2 & 2.4 & 3.3 & - & - & 1.5 & 5.5 & - \\
\hline Method was inconvenient & 3.2 & 2.6 & 4.9 & 3.3 & 2.6 & 3.8 & 2.5 & 4.1 & 5.1 \\
\hline Others & 14.2 & 14.7 & 13.4 & 14.6 & 13.2 & 15.4 & 16.3 & 9.6 & 12.8 \\
\hline \multicolumn{10}{|c|}{ Number of current non-user: reason for non-user } \\
\hline $\begin{array}{l}\text { Lack of knowledge about family } \\
\text { planning method }\end{array}$ & 6.0 & 6.3 & 4.1 & 6.2 & 4.3 & 6.9 & 6.6 & 3.2 & 4.1 \\
\hline Against the religion & 1.6 & 1.6 & 2.1 & 1.8 & 1.1 & - & 1.7 & 1.6 & 0.8 \\
\hline Opposed to family planning & 3.1 & 3.3 & 2.5 & 3.4 & 1.6 & 2.0 & 3.4 & 2.5 & - \\
\hline Husband opposed & 8.7 & 8.8 & 8.0 & 8.3 & 11.7 & 6.9 & 8.7 & 7.8 & 10.7 \\
\hline Other family members opposed & 2.4 & 2.7 & 2.4 & 2.3 & 3.3 & 2.0 & 2.1 & 3.4 & 5.0 \\
\hline Not like existing method & 3.5 & 3.4 . & 4.1 & 3.7 & 2.4 & 2.0 & 3.4 & 3.9 & 3.3 \\
\hline Afraid of sterilization & 7.3 & 7.2 & 7.5 & 7.7 & 5.7 & 3.9 & 7.6 & 6.4 & 5.0 \\
\hline Can not work after sterilization & 1.8 & 1.7 & 1.8 & 1.9 & 0.8 & 1.0 & 2.0 & 0.7 & 1.7 \\
\hline Worry about side effect & 2.0 & 2.1 & 1.4 & 1.9 & 1.9 & 3.0 & 2.1 & 1.1 & 3.3 \\
\hline Cost too much & 2.7 & 2.8 & 2.1 & 3.0 & 1.4 & 1.0 & 3.0 & 1.8 & - \\
\hline Health dose not permit & 13.8 & 13.4 & 16.2 & 13.6 & 15.2 & 12.7 & 13.4 & 14.6 & 18.2 \\
\hline Hard/inconvenient to get method & 2.2 & 2.2 & 1.8 & 2.5 & 0.5 & 2.0 & 2.2 & 1.8 & 1.7 \\
\hline Difficult to became pregnant & 1.5 & 1.6 & 1.1 & 1.3 & 1.9 & 3.9 & 1.2 & 2.7 & 3.3 \\
\hline
\end{tabular}

\section{Logistic regression}

Logistic regression analysis has been carried out for the future intention to use contraceptive. The dependent variable here is the future intension of contraceptive use, (coded as a dichotomous variable; 0 when no use was intended and as 1 when there was a desire).

Results based on the logistic regression analysis shows that urban women are more likely to use contraceptive in future than rural women, though it does not show any significant relationship. Educational status of the women has positive impact on future intention of contraceptive use. To elaborate with, in response to the illiterate women, those educated up to secondary and above are more likely to report future intension of contraceptive use. Interestingly, women cutting across different standard of living do not show any significant differential. But the women who reported having advised by ANM/health workers show more chances of using contraception in future as compared to those who are not advised on such ground. We tried to check whether there exists any differential of future contraceptive use intension among the women showing different reasons behind current non-use. As shown in the table, in response to the women who stated 'lack of knowledge' behind current non-use, the women showing reasons such as 'health problems' or 'method related problems' are more likely to use contraceptive method in future. Probably it can be inferred that lack of knowledge is the 
prime barrier against current non-use of contraception or even for future intension.

To summarize, the women with better educational status, advised by ANM/health workers and having knowledge of contraception have more chances to use in future, though they reported to have never used any contraceptive method.

Table 8: Impact of selected background characteristics on the intention of contraceptive use in future among non-users.

\begin{tabular}{|c|c|c|}
\hline $\begin{array}{l}\text { Background } \\
\text { characteristics }\end{array}$ & $\operatorname{Exp}(\beta)$ & $\begin{array}{l}\text { Number } \\
\text { of women }\end{array}$ \\
\hline \multicolumn{3}{|l|}{ Type of residence } \\
\hline Rural® & & 2350 \\
\hline Urban & 1.024 & 437 \\
\hline \multicolumn{3}{|l|}{ Education } \\
\hline Illiterate® & 1.000 & 2318 \\
\hline Up to $9^{\text {th }}$ & $1.550 * * *$ & 369 \\
\hline 10 and above & $2.253 * * *$ & 100 \\
\hline \multicolumn{3}{|l|}{ Standard of living } \\
\hline Low® & & 2232 \\
\hline Medium & 1.107 & 436 \\
\hline High & 1.150 & 119 \\
\hline \multicolumn{3}{|c|}{ Advised by ANM/health worker } \\
\hline No® & & 2544 \\
\hline Yes & $2.946 * * *$ & 243 \\
\hline \multicolumn{3}{|c|}{ Reason for not using contraception } \\
\hline Lack of knowledge $®$ & & 167 \\
\hline Opposition & 1.363 & 441 \\
\hline Health problem & $1.839 * *$ & 386 \\
\hline $\begin{array}{l}\text { Misconception regarding } \\
\text { Contraceptives and } \\
\text { monetary problem }\end{array}$ & $2.440 * * *$ & 1793 \\
\hline Constant & $0.766 *$ & 2787 \\
\hline \multicolumn{3}{|c|}{$\begin{array}{l}\text { Dependent variable: future intention to use method: No } \\
(0) \text {, Yes (1) }\end{array}$} \\
\hline Significant level: $* \mathrm{P}<0.05$; & $* \mathrm{P}<0.01 ; * *$ & $\mathrm{P}<0.001$ \\
\hline
\end{tabular}

\section{DISCUSSION}

In this paper, we set out to find out knowledge and use of contraceptive methods and explore the future contraceptive intention with reference to informed choice. The paper very contributory to the discipline of contraception studies in the sense that it highlights status and gap in contraceptive use by the scheduled caste community of high fertility state of Uttar Pradesh. Women of SC community in UP are a great contributor to the fertility and understanding the dynamics of contraceptive use among them would help the policy makers capture the tempo of fertility among them. As the paper, has attempted in the direction of understanding the contraceptive among also those who intends to use contraceptive and who wants their future child, this is a very important piece of research in the direction of reducing fertility in a high fertility state.
There is a positive relationship between knowledge of contraceptive methods and place of residence, level of education and standard of living. Surprisingly, there is positive relationship between knowledge of traditional methods of contraception, level of education and standard of living. Use of contraceptive methods among these groups of women is substantially low, but it follows an expected trend, that is, positive relationship between use of contraceptive methods and place of residence, level of education, standard of living, age and surviving children. There is a distinct difference in use of contraception by number of living son compared to number of daughters. Government health care institutions remain the main source of contraception for scheduled caste women. Very negligible percentage of women (currently non users) informed for contraceptive methods by health workers and their emphasis on female sterilization may be the reason of very less contraceptive prevalence rate among scheduled caste women in Uttar Pradesh. Result from the logistic analysis gives a clear picture that women with the information/knowledge are more likely to use the method in the near future.

\section{Funding: No funding sources \\ Conflict of interest: None declared \\ Ethical approval: Not required}

\section{REFERENCES}

1. Visaria L, Visaria P. Reproductive health in policy and practice: India. In: Visaria L, Visaria P, eds. PRB. Document No.: 140736. Washington, D.C.; Population Reference Bureau. 1998: 1-36.

2. Mishra VK, Retherford RD, Nair PS, Feeney G. Reason for discontinuing \& not intending to use contraception in India. In: Mishra VK, Retherford RD, Nair PS, Feeney G, eds. National Family Health Survey-2. Subject Reports No.13. Mumbai: International Institute for Population Sciences; 1999: 5-36.

3. IIPS. National Family Health Survey II, India (1998-99). In: T. K. Roy, eds. IIPS. Mumbai: International Institute for Population Sciences; 2000: 1-439.

4. IIPS. National Family Health Survey II, UttarPradesh - (1998-99). In: IIPS. Mumbai: International Institute for Population Sciences; 2000: 1-21.

5. Verma RK, Baburajan PK. Determinant of contraceptive choice in India. J Family Welfare. 1994;40(3):1-8.

6. Gupta YP, Talwar PP, Agrawal K, Sawney N. Family planning knowledge, interest and information needs of district officials in Uttar Pradesh. J Family Welfare. 1994;40(3):9-18.

7. Asari VG. Determinants of contraceptive use in Kerala: the case study of son/daughter preferences. J Family Welfare. 1994;40(3):19-25.

8. Roy TK, Paswan B. Demand for family planning among scheduled caste and scheduled Tribes. In: Hari Mohan Mathur, eds. The Family Welfare 
Program in India. 1st ed. Uttar Pradesh: Vikas Publishing; 2001: 157-175.

9. Krishnamohan PVT, Khan AG, Sunder S. Two-child family norm: women attitude in Uttar Pradesh, 1996. J Family Welfare. 2003;49(1):21-31.

10. Moursund A, Kravdal O. individual and community effects of women's education and autonomy on contraceptive use in India. Popul Stud. 2003;57(3):285-301.
11. Riyami AA, Mabry. Women's autonomy, education and employment in oman and their influence on contraceptive use. Reprod Health Matters. 2001;12(23):144-54.

DOI: $10.5455 / 2320-1770$. ijrcog20140925

Cite this article as: Singh MN, Joshi N. Dynamics of contraceptive use among schedule caste women in Uttar Pradesh. Int J Reprod Contracept Obstet Gynecol 2014;3:566-74. 